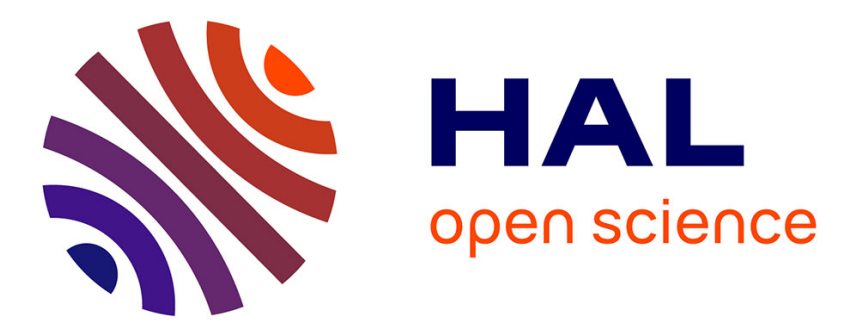

\title{
Molecular, 13C, and 14C evidence for the allochthonous and ancient origin of C16-C18 n-alkanes in modern soils
}

Eric Lichtfouse, Gérard Bardoux, André A. Mariotti, Jérôme Balesdent, Donna C. Ballentine, Stephen A. Macko

\section{- To cite this version:}

Eric Lichtfouse, Gérard Bardoux, André A. Mariotti, Jérôme Balesdent, Donna C. Ballentine, et al.. Molecular, 13C, and 14C evidence for the allochthonous and ancient origin of C16-C18 n-alkanes in modern soils. Geochimica et Cosmochimica Acta, 1997, 61 (9), pp.1891-1898. 10.1016/S00167037(97)00021-5 . hal-00193102

\section{HAL Id: hal-00193102 \\ https://hal.science/hal-00193102}

Submitted on 30 Nov 2007

HAL is a multi-disciplinary open access archive for the deposit and dissemination of scientific research documents, whether they are published or not. The documents may come from teaching and research institutions in France or abroad, or from public or private research centers.
L'archive ouverte pluridisciplinaire HAL, est destinée au dépôt et à la diffusion de documents scientifiques de niveau recherche, publiés ou non, émanant des établissements d'enseignement et de recherche français ou étrangers, des laboratoires publics ou privés. 
Revised version

Geochimica et Cosmochimica Acta 61, 1891-1898, 1997.

doi:10.1016/S0016-7037(97)00021-5

Correspondence: Dr. Eric Lichtfouse, INRA-CMSE-PME, 17, rue Sully, 21000 Dijon, France

Eric.Lichtfouse@dijon.inra.fr

\title{
Molecular, ${ }^{13} \mathrm{C}$ and ${ }^{14} \mathrm{C}$ evidence for the allochthonous and ancient origin of $\mathrm{C}_{16}-\mathrm{C}_{18} \boldsymbol{n}$-alkanes in modern soils.
}

\author{
ÉRIC LICHTFOUSE, JÉRÔME BALESDENT, GÉRARD BARDOUX, \\ DONNA C. BALLENTINE and STEPHEN A. MACKO
}

\begin{abstract}
The heterogeneous isotopic composition of $\mathrm{C}_{3}$ and $\mathrm{C}_{4}$ plants can be used to to follow the fate of plant carbon into soil organic molecules. Thus, after 23 years of cropping of maize $\left(\mathrm{C}_{4}\right)$ on a soil which was previously under $\mathrm{C}_{3}$ vegetation, $\mathrm{C}_{25}$ - $\mathrm{C}_{33}$ soil $n$-alkanes are ${ }^{13} \mathrm{C}$-enriched up to $9 \%$ relatively to the initial $\mathrm{C}_{3}$ soil, reflecting the input of ${ }^{13} \mathrm{C}$-enriched $n$-alkanes from maize waxes. In sharp contrast, $\mathrm{C}_{16}$ - $\mathrm{C}_{18}$ soil $n$-alkanes do not show any significant ${ }^{13} \mathrm{C} /{ }^{12} \mathrm{C}$ variation over the same time interval. This absence of isotopic variation, along with consideration of their relative concentration, absolute concentration and biodegradability, demonstrate that these substances must represent a regular input from an external source. Evidence of a large contribution of an ancient source, amounting to more than $65 \%$ of the alkane fraction, is given by a ${ }^{14} \mathrm{C}$-age of $8510 \mathrm{yrs} \mathrm{BP}$. Moreover, short-chain $n$-alkanes from soils, diesel fuel, diesel automobile exhaust and petroleum products exhibit similar distributions and $\delta^{13} \mathrm{C}$ values. These findings suggests that $\mathrm{C}_{16} \mathrm{C}^{-} \mathrm{C}_{18}$ soil $n$-alkanes represent a non-point source pollution of ancient hydrocarbons either carried by aerosols or entering the soil via continuous hydrocarbon seepage from the deep sedimentary rocks of the Paris basin.
\end{abstract}

\section{INTRODUCTION}

$n$-Alkanes are widely occurring in geological samples such as soils, sediments, coals and petroleums. Like most molecular fossils, the precice origin of these substances, their role within the biogeochemical carbon cycle and the nature of processes involved in their transformation are still under speculation (KISSIN, 1987, GRIMALT and AlBAigÉs, 1987, TEgElAAR et al., 1989, SiCRE et al., 1990, DinEl et al., 1990, LICHTFOUSE and COLLISTER, 1992, de LEEUW and LARGEAU, 1993, FREEMAN et al., 1994, COLLISTER et al., 1994, SPOONER et al., 1994, AMBLÈS et al., 1994). In recent studies we have shown that plants of distinct ${ }^{13} \mathrm{C} /{ }^{12} \mathrm{C}$ compositions, the so-called $\mathrm{C}_{3}$ and $\mathrm{C}_{4}$ plants, can be used as natural tracers in field experiments to study the origin and the dynamics of organic carbon from soil substances (BALESDENT et al., 1987, LICHTFOUSE et al., 1994a, LICHTFOUSE and BUDZINSKI, 1995, LICHTFOUSE, 1995, 1996). Indeed, those studies were based on isotopic variations observed after a change from $\mathrm{C}_{3}$ to $\mathrm{C}_{4}$ vegetation. Here, we show that the absence of isotopic variation of individual $n$-alkanes in such experiments can also provide some information on their source.

\section{Soil analysis}

\section{EXPERIMENTAL}

Zea mays was grown in two experimental fields at one crop per year on soils which have previously been cultivated only with $\mathrm{C}_{3}$ plants. Soils were cropped during 5 years at La Minière and 23 years at Boigneville, France. Geological information on these soils is available elsewhere (BALABANE and BALESDENT, 1992, BALESDENT et al., 1990). 
Vertical cores through the $0-35 \mathrm{~cm}$ ploughed horizon were taken at nine random locations, well-mixed, dried at $20^{\circ} \mathrm{C}$ then sieved to $2 \mathrm{~mm}$.

A similar fractionation procedure is described by LICHTFOUSE et al. (1994b). Drastic precautions were taken to prevent contamination. Typically, $100 \mathrm{~g}$ of sieved dried soil (total organic carbon $\sim 1 \%$ ) were finely ground and extracted three times by sonication at $30^{\circ} \mathrm{C}$ with $\mathrm{CHCl}_{3}-\mathrm{MeOH}(3: 1 \mathrm{v} / \mathrm{v})$ to give about $18.0 \mathrm{mg}$ of extract. The extract was fractionated into neutral $(\sim 9.0 \mathrm{mg})$ and acid $(\sim 3.6 \mathrm{mg})$ fractions by column chromatography on KOH impregnated silica gel (MCCARTHY and DUTHIE, 1962). The neutral fraction was then fractionated by thin layer chromatography (TLC) on fluorescein impregnated silica gel $\left(0.25\right.$ or $0.5 \mathrm{~mm}$ thickness, $\left.\mathrm{CH}_{2} \mathrm{Cl}_{2}\right)$, with 1,2:3,4-dibenzanthracene, cholesterol and friedelin as side-references, to give a hydrocarbon-ester fraction $\left(\sim 3.2 \mathrm{mg}, R_{\mathrm{F}}>\sim 0.85\right)$, a ketone fraction $\left(\sim 2.0 \mathrm{mg}, R_{\mathrm{F}} \sim\right.$ $0.28-0.85)$, an alcohol fraction $\left(\sim 2.0 \mathrm{mg}, R_{\mathrm{F}} \sim 0.06-0.28\right)$ and a polar fraction $(\sim 1.8 \mathrm{mg}$, $\left.R_{\mathrm{F}}<\sim 0.06\right)$. The hydrocarbon-ester fraction was then fractionated by TLC on fluorescein impregnated silica gel ( $0.25 \mathrm{~mm}$ thickness, $n$-hexane), with $n$-octacosane, 1-phenyldodecane, 2-methylphenanthrene and 1,2:3,4-dibenzanthracene as sidereferences, to give an alkane fraction $\left(\sim 1.5 \mathrm{mg}, R_{\mathrm{F}}>\sim 0.87\right)$, an aromatic fraction $(\sim 0.9$ $\left.\mathrm{mg}, R_{\mathrm{F}} \sim 0.15-0.87\right)$, and an ester fraction $\left(\sim 0.8 \mathrm{mg}, R_{\mathrm{F}}<\sim 0.15\right)$.

Gas chromatography (GC) analyses of $n$-alkanes from alkane fractions were performed using a Hewlett Packard GC 5990 fitted with an on-column injector and, either a flame ionization detector (FID) or a HP 5989A quadrupole mass spectrometer. Relative concentrations were obtained by integration of FID peak areas. Absolute concentrations were calculated by comparison with the area of an internal standard, $5 \alpha$-androstane. Isotopic analyses were carried out under continuous helium flow using an $\mathrm{HP} 5990 \mathrm{GC}$ coupled to a $\mathrm{CuO}$ furnace $\left(850^{\circ} \mathrm{C}\right)$, and a cryogenic trap $\left(-100^{\circ} \mathrm{C}\right)$ coupled to a VG Optima mass spectrometer, monitoring continuously ion currents at $\mathrm{m} / \mathrm{z}=44,45$ and 46 . Isotopic compositions are expressed in per mil. relative to the Pee Dee Belemnite standard: $\delta^{13} \mathrm{C}=\left[\left({ }^{13} \mathrm{C} /{ }^{12} \mathrm{C}\right.\right.$ sample $-{ }^{13} \mathrm{C} /{ }^{12} \mathrm{C}$ std $) /\left({ }^{13} \mathrm{C} /{ }^{12} \mathrm{C}\right.$ std $\left.)\right] \times 10^{3}$, where ${ }^{13} \mathrm{C} /{ }^{12} \mathrm{C}$ std $=0.0112372$. The $\delta^{13} \mathrm{C}$ values of maize wax $n$-alkanes are $-19.0 \%$ o $\left(\mathrm{C}_{25}\right)$, -19.1\%o $\left(\mathrm{C}_{27}\right),-18.4 \%$ o $\left(\mathrm{C}_{29}\right)$, -20.6\%o $\left(\mathrm{C}_{31}\right)$ and -22.2\%o $\left(\mathrm{C}_{33}\right)$ (LICHTFOUSE $e t$ al., 1994c).

An alkane fraction from a soil cultivated 4 years at La Minière field was ${ }^{14} \mathrm{C}$-dated as described elsewhere (EGLINTON et al., 1996, LiCHTFOUSE and EGLINTON, 1995). Accelerator Mass Spectrometry dating indicated a radiocarbon age of $8510 \pm 120 \mathrm{yrs}$ before the present (BP) corresponding to a fraction Modern (fM) of $\sim 0.35$.

\section{Diesel analysis}

A sample of diesel from an automobile as well as a sample of exhaust from the same vehicle were obtained. Particulate exhaust was collected on an ashed $\left(550^{\circ} \mathrm{C}, 1\right.$ hour) glass fiber filter using a low volume $(60-100 \mathrm{~L} / \mathrm{min})$ air sampler. The filter was immediately immersed in dichloromethane and stored in a sealed vial at $4{ }^{\circ} \mathrm{C}$ until analysis.

Approximately $1 \mathrm{~mL}$ of diesel fuel was charged to an ash glass column fitted with a teflon stopcock and containing $2.5 \mathrm{~g}$ silica (J. T. Baker, 40-140 mesh) and $1.6 \mathrm{~g}$ alumina (Fisher Scientific, 80-200 mesh) in a hexane slurry. Both adsorbents were 
activated at $200^{\circ} \mathrm{C}$ for 4 hours and stored under desication prior to use (DURAND, 1970). The alkanes were isolated from the aromatic components by elution from the column using $18 \mathrm{~mL}$ hexane and were concentrated under vacuum desiccation prior to instrumental analysis. The exhaust aerosol filter was extracted in $150 \mathrm{~mL}$ dichloromethane for 16 hours using a Soxhlet procedure. The dichloromethane in which the aerosol filter was immersed was filtered gravimetrically to remove soot particles and was combined with the aerosol filter extract. The combined extract was concentrated by rotoevaporation at $<30^{\circ} \mathrm{C}$ and the alkanes were isolated from the aromatic fraction using the same procedure as described above.

Table 1. Carbon isotopic composition of soil $n$-alkanes

\begin{tabular}{|c|c|c|c|c|c|c|c|c|}
\hline $\begin{array}{l}\text { TIME } \\
\text { (years) }\end{array}$ & $\begin{array}{l}\mathbf{C}_{16} \\
(\%)\end{array}$ & $\begin{array}{l}\mathbf{C}_{17} \\
(\% 0)\end{array}$ & $\begin{array}{l}\mathbf{C}_{\mathbf{1 8}} \\
(\%)\end{array}$ & $\begin{array}{l}\mathbf{C}_{25} \\
(\%)\end{array}$ & $\begin{array}{l}\mathbf{C}_{27} \\
(\% 0)\end{array}$ & $\begin{array}{l}\mathbf{C}_{29} \\
(\%)\end{array}$ & $\begin{array}{l}\mathbf{C}_{\mathbf{3 1}} \\
(\%)\end{array}$ & $\begin{array}{l}\mathbf{C}_{33} \\
(\%)\end{array}$ \\
\hline \multicolumn{9}{|c|}{ La Minière field experiment } \\
\hline 0.00 & $\begin{array}{c}-29.0 \\
(0.8)\end{array}$ & $\begin{array}{c}-30.2 \\
(0.8)\end{array}$ & $\begin{array}{l}-29.2 \\
(0.6)\end{array}$ & $\begin{array}{c}-34.6 \\
(0.3)\end{array}$ & $\begin{array}{c}-34.2 \\
(0.3)\end{array}$ & $\begin{array}{l}-35.7 \\
(0.3)\end{array}$ & $\begin{array}{l}-35.7 \\
(0.3)\end{array}$ & $\begin{array}{l}-35.7 \\
(0.3)\end{array}$ \\
\hline 0.42 & $\begin{array}{c}-29.6 \\
(0.7)\end{array}$ & $\begin{array}{l}-29.8 \\
(0.7)\end{array}$ & $\begin{array}{l}-29.7 \\
(0.8)\end{array}$ & $\begin{array}{c}-32.3 \\
(0.3)\end{array}$ & $\begin{array}{c}-32.5 \\
(0.3)\end{array}$ & $\begin{array}{l}-35.3 \\
(0.5)\end{array}$ & $\begin{array}{l}-35.2 \\
(0.5)\end{array}$ & n.d. \\
\hline 1.00 & $\begin{array}{c}-28.9 \\
(0.5)\end{array}$ & $\begin{array}{c}-29.6 \\
(0.7)\end{array}$ & $\begin{array}{c}-28.4 \\
(0.7)\end{array}$ & $\begin{array}{c}-31.6 \\
(0.3)\end{array}$ & $\begin{array}{r}-32.7 \\
(0.3)\end{array}$ & $\begin{array}{l}-35.5 \\
(0.3)\end{array}$ & $\begin{array}{l}-35.8 \\
(0.3)\end{array}$ & $\begin{array}{l}-35.7 \\
(0.3)\end{array}$ \\
\hline 1.42 & $\begin{array}{c}-29.5 \\
(0.6)\end{array}$ & $\begin{array}{c}-29.4 \\
(0.8)\end{array}$ & $\begin{array}{l}-28.7 \\
(0.6)\end{array}$ & $\begin{array}{l}-31.7 \\
(0.3)\end{array}$ & $\begin{array}{c}-32.1 \\
(0.3)\end{array}$ & $\begin{array}{l}-35.4 \\
(0.3)\end{array}$ & $\begin{array}{l}-35.6 \\
(0.3)\end{array}$ & $\begin{array}{l}-35.7 \\
(0.3)\end{array}$ \\
\hline 1.75 & $\begin{array}{c}-29.5 \\
(0.5)\end{array}$ & $\begin{array}{c}-30.1 \\
(0.5)\end{array}$ & $\begin{array}{l}-29.0 \\
(0.5)\end{array}$ & $\begin{array}{c}-31.6 \\
(0.3)\end{array}$ & $\begin{array}{c}-32.3 \\
(0.3)\end{array}$ & $\begin{array}{l}-35.5 \\
(0.3)\end{array}$ & $\begin{array}{l}-35.5 \\
(0.3)\end{array}$ & $\begin{array}{l}-35.4 \\
(0.3)\end{array}$ \\
\hline 2.42 & $\begin{array}{c}-29.7 \\
(0.5)\end{array}$ & $\begin{array}{c}-30.3 \\
(0.5)\end{array}$ & $\begin{array}{l}-29.5 \\
(0.8)\end{array}$ & $\begin{array}{c}-30.6 \\
(0.5)\end{array}$ & $\begin{array}{c}-31.1 \\
(0.3)\end{array}$ & $\begin{array}{l}-35.1 \\
(0.3)\end{array}$ & $\begin{array}{l}-35.0 \\
(0.3)\end{array}$ & $\begin{array}{l}-35.2 \\
(0.3)\end{array}$ \\
\hline 3.42 & $\begin{array}{c}-29.5 \\
(0.5)\end{array}$ & $\begin{array}{c}-30.4 \\
(0.5)\end{array}$ & $\begin{array}{l}-29.1 \\
(0.6)\end{array}$ & $\begin{array}{l}-29.9 \\
(0.3)\end{array}$ & $\begin{array}{l}-29.5 \\
(0.3)\end{array}$ & $\begin{array}{r}-34.7 \\
(0.3)\end{array}$ & $\begin{array}{l}-34.0 \\
(0.4)\end{array}$ & $\begin{array}{l}-33.9 \\
(0.4)\end{array}$ \\
\hline 4.00 & $\begin{array}{c}-29.4 \\
(0.8)\end{array}$ & $\begin{array}{c}-30.3 \\
(0.5)\end{array}$ & $\begin{array}{l}-29.6 \\
(0.6)\end{array}$ & n.d. & $\begin{array}{c}-29.7 \\
(0.3)\end{array}$ & $\begin{array}{l}-34.5 \\
(0.3)\end{array}$ & $\begin{array}{l}-34.4 \\
(0.3)\end{array}$ & $\begin{array}{l}-33.6 \\
(0.5)\end{array}$ \\
\hline 4.33 & $\begin{array}{c}-29.3 \\
(0.5)\end{array}$ & $\begin{array}{c}-30.0 \\
(0.6)\end{array}$ & $\begin{array}{l}-29.5 \\
(0.6)\end{array}$ & $\begin{array}{l}-30.2 \\
(0.3)\end{array}$ & $\begin{array}{c}-29.5 \\
(0.3)\end{array}$ & $\begin{array}{l}-34.3 \\
(0.3)\end{array}$ & $\begin{array}{r}-33.7 \\
(0.3)\end{array}$ & $\begin{array}{c}-33.4 \\
(0.3)\end{array}$ \\
\hline Average $^{\dagger}$ & $\begin{array}{l}-29.4 \\
(0.3)\end{array}$ & $\begin{array}{l}-30.0 \\
(0.3)\end{array}$ & $\begin{array}{l}-29.2 \\
(0.4)\end{array}$ & & & & & \\
\hline
\end{tabular}

\section{Boigneville field experiment}

$\begin{array}{ccccccccc}\text { Wheat }^{*} & -29.7 & -31.6 & -29.8 & \text { n.d. } & -33.0 & -35.7 & -35.7 & -33.7 \\ & (0.6) & (0.7) & (0.6) & & (0.3) & (0.3) & (0.3) & (0.3) \\ 20.0 & -29.7 & -31.5 & -29.8 & \text { n.d. } & -24.1 & -28.8 & -28.7 & -26.7 \\ & (0.8) & (0.8) & (0.8) & & (0.3) & (0.3) & (0.3) & (0.3) \\ 23.0 & -28.3 & -28.9 & -28.1 & \text { n.d. } & -24.0 & -28.3 & -28.1 & -25.6 \\ & (0.5) & (0.5) & (0.5) & & (0.3) & (0.3) & (0.3) & (0.3)\end{array}$

Note: $\delta^{13} \mathrm{C}$ values of soil $n$-alkanes versus time of maize cultivation. ${ }^{*}$ Soil cultivated 23 years with wheat. The average deviation of 3-4 replicates are given in parenthesis. ${ }^{\dagger}$ Calculated mean deviation in parenthesis. n. d. = not determined. 
The alkanes were characterized with a Hewlett Packard (HP) 5890 series II gas chromatograph equipped with an HP-1 (12m x $0.2 \mathrm{~mm}$ i.d.) column which was interfaced to a HP 5971 mass selective detector (GC/MS). The GC temperature program was as follows : hold at $70^{\circ} \mathrm{C}$ for $2 \mathrm{~min}$, increase at a rate of $6^{\circ} \mathrm{C} / \mathrm{min}$ to $280^{\circ} \mathrm{C}$, hold at $280^{\circ} \mathrm{C}$ for $20 \mathrm{~min}$. Compound specific carbon isotope data were obtained using a VG Prism series II isotope ratio mass spectrometer (IRMS) and a Hewlett Packard 5890 series II GC equipped with the same column as above and coupled through a combustrion furnace and water trap to the VG Prism ratio mass spectrometer (GC/C/IRMS).

\section{RESULTS AND DISCUSSION}

\section{${ }^{13}$ C Labelling of Soil Organic Molecules at Natural Abundance}

A labelling experiment with carbon 13 at natural abundance has been designed to follow the fate of plant carbon into soil organic matter. Thus, maize, a $\mathrm{C}_{4}$ plant, has been cultivated at two sites on soils which were previously cultivated with isotopically

distinct $\mathrm{C}_{3}$ plants. Maize has been cultivated at one crop per year over a 5-year period at the La Minière site and over a 23-year period at the Boigneville site. The carbon isotopic composition of $n$-alkanes from those soils are reported in Table 1.

The isotopic compositions of $\mathrm{C}_{25}-\mathrm{C}_{33} n$-alkanes from soils increase with increasing time of maize cultivation (Figure 1). It has been shown that this increase resulted from the input of ${ }^{13} \mathrm{C}$-enriched $n$-alkanes from maize waxes into soil organic matter (LICHTFOUSE et al., 1994a, LICHTFOUSE, 1995, 1996). It is even possible to calculate the contribution of maize $n$-alkane to each soil $n$-alkane at any time of cultivation, using the following equation:

$$
M=100 .\left(\delta-\delta_{0}\right) /\left(\delta_{m}-\delta_{0}\right)
$$

where $\mathrm{M}$ is the carbon percentage (or mass percentage) of maize $n$-alkane within soil $n$-alkane, $\delta$ is the isotopic composition of soil $n$-alkane at a given time of cultivation, $\delta_{0}$ is the isotopic composition of soil $n$-alkane before maize cultivation and $\delta_{\mathrm{m}}$ is the isotopic composition of leaf wax $n$-alkane. For instance, after 23 years of maize cultivation, $\mathrm{M}$ reaches $50.3 \%$ for the $\mathrm{C}_{31} n$-alkane. These experiments under natural conditions can therefore give access to the dynamics of individual organic substances.

\section{Isotopic Compositions of Soil $\mathbf{C}_{16}-\mathbf{C}_{18} \boldsymbol{n}$-alkanes}

In contrast, $\mathrm{C}_{16}, \mathrm{C}_{17}$ and $\mathrm{C}_{18}$ soil $n$-alkanes show, within the experimental error, constant $\delta{ }^{13} \mathrm{C}$ values over the 5-year experiment at La Minière, averaging at $-29.4 \%$, $30.0 \%$ and $-29.2 \%$ respectively (Table 1, Figure 1). Moreover, even after 23 years of maize cultivation at the Boigneville field, no isotopic increase is apparent for $\mathrm{C}_{16}-\mathrm{C}_{18}$ $n$-alkanes $(\sim-28.4 \%)$. This absence of isotopic variation on these long-term experiments demonstrates that these $n$-alkanes must derive from an external source, as explained below. 

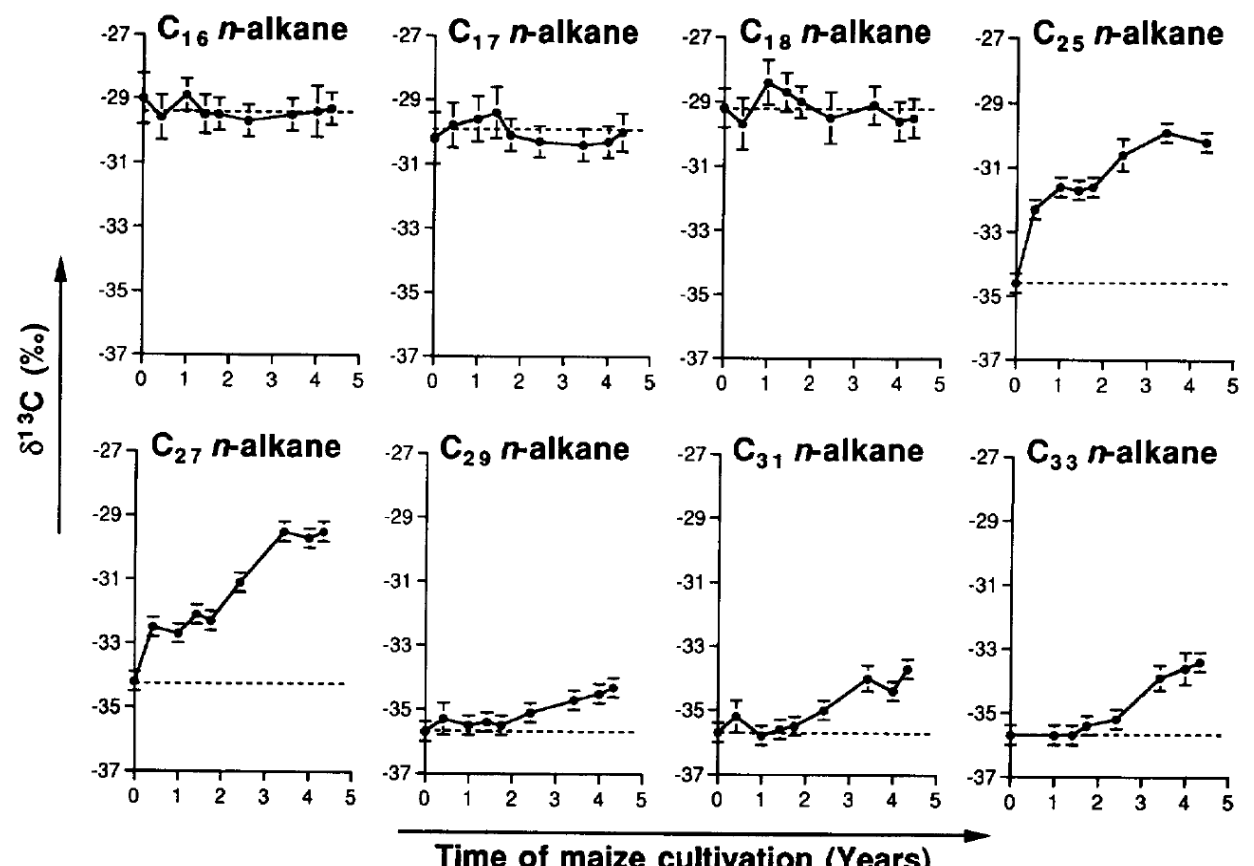

Figure $1 . \delta^{13} \mathrm{C}$ isotopic compositions of $n$-alkanes from soils cultivated maize. Note the absence of significant variations of $\mathrm{C}_{16}$ - $\mathrm{C}_{18}{ }^{n}$-alkanes $\delta^{13} \mathrm{C}$ values over the 5 -year period.

The absence of isotopic variation shows that $\mathrm{C}_{16}-\mathrm{C}_{18} n$-alkanes are not derived from soil biomass. Indeed, if those substances were to derive from certain soil organisms, they should have integrated at least a small portion of heavy maize-derived carbon. This is especially true after 23 years of cultivation, where the maize carbon content of $\mathrm{C}_{31}$ $n$-alkane is $50.3 \%$. Moreover, because short-chain $n$-alkanes are more biodegradable, more volatile and more susceptible to weathering and water-washing than higher homologues (VOLKMAN et al., 1983, BOSSERT and BARTHA, 1984, PETERS and MOLDOWAN, 1993), one would expect a higher turnover and thus a higher maizederived carbon content for $\mathrm{C}_{16}-\mathrm{C}_{18}$ soil $n$-alkanes. This rapid degradation of shortchain $n$-alkanes is well supported by an incubation of $\mathrm{C}_{20} n$-alkane into a rendzina soil, which show that $25 \%$ of this component is mineralized only after 8 weeks (AMBLÈS et $a l ., 1994)$. On the contrary, the lack of isotopic variation of $\mathrm{C}_{16}-\mathrm{C}_{18}$ soil $n$-alkanes in our experiments indicates that their carbon does not derive from the soil biomass. These results are also supported by incubation of soils from Grignon, France, with ${ }^{13} \mathrm{C}$ labelled glucose, showing that all $n$-alkanes in the $\mathrm{C}_{16}-\mathrm{C}_{35}$ range do not incorporate heavy carbon from glucose (LICHTFOUSE et al., 1995).

The distribution of $\mathrm{C}_{15}-\mathrm{C}_{18}$ soil $n$-alkanes do not show any strong predominance of odd (or even) carbon-number homologues (Figure 2). This feature is typical of hydrocarbons occurring in mature, ancient sedimentary organic matter such as fossil fuels (TISSOT et al., 1971, TISSOT and WELTE, 1984). To check this possible contribution of ancient carbon, a soil alkane fraction was analysed for ${ }^{14} \mathrm{C}$. AMS dating indicated a radiocarbon age of $8510 \pm 120$ yrs before the present (BP) corresponding to a fraction Modern ( $\mathrm{fM}$ ) of $\sim 0.35$. If we assume that this fraction is a mixture of modern $\mathrm{C}$ and fossil fuel $\mathrm{C}$ (no ${ }^{14} \mathrm{C}$ ), then the fraction Modern indicates that there is $35 \%$ of modern $\mathrm{C}$ and $65 \%$ of fossil-fuel $\mathrm{C}$. In fact, $65 \%$ represents a minimum value for fossil- 
fuel carbon because incoporation of some bomb-derived ${ }^{14} \mathrm{C}$ into the biomass gives rise to overestimation of $\mathrm{fM}$ values (LICHTFOUSE and EGLINTON, 1995). This additional isotopic evidence therefore demonstrates unambigously the occurrence of ancient carbon in the soil alkane fraction.

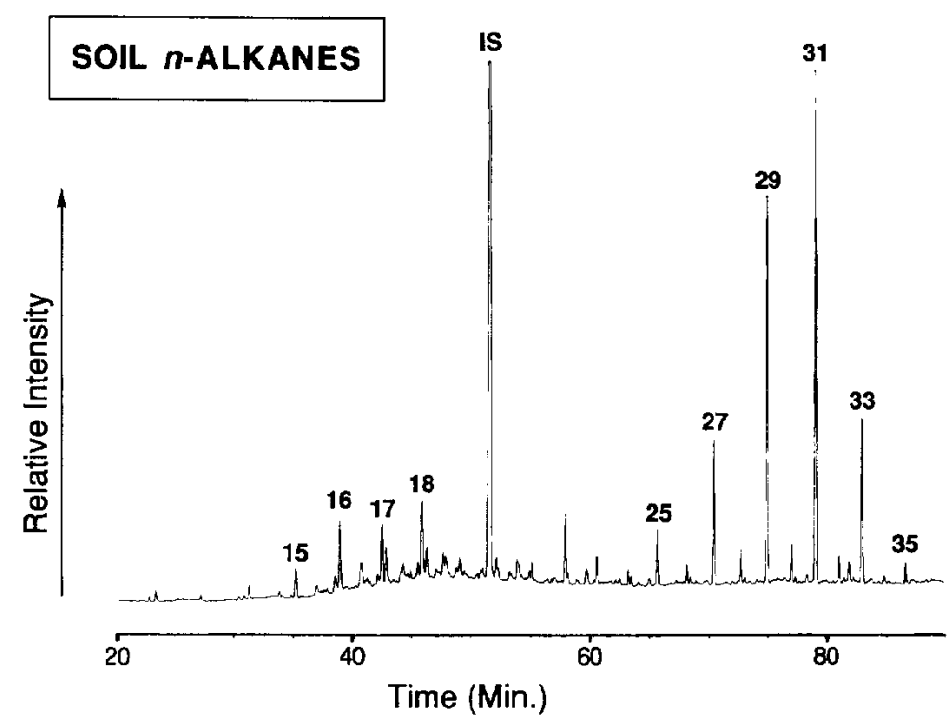

Figure 2. Typical distribution of $n$-alkanes from alkane fractions of soil organic extracts (this chromatogram from the La Minière field experiment after 4 years of maize cultivation). IS: Internal Standard, $5 \alpha$-androstane. Carbon number of $n$-alkanes are drawn on top of peaks. Conditions: gas chromatography fitted with a flame ionization detector; fused-silica capillary column HP Ultra 1 (25 m x $0.20 \mathrm{~mm}) ; 100 \%$ methylsilicone phase $(0.11 \mu \mathrm{m})$; helium carrier gas $(1 \mathrm{ml} / \mathrm{min})$. Temperature: $50^{\circ} \mathrm{C}(2$ $\min ), 50-320^{\circ} \mathrm{C}$ at $3 \% \mathrm{~min}, 320^{\circ} \mathrm{C}(60 \mathrm{~min})$.

\section{Diesel $n$-alkanes}

The $n$-alkanes from diesel fuel and diesel automobile exhaust range from $\mathrm{C}_{12}$ to $\mathrm{C}_{24}$ with no even or odd predominance (Figure 3 and 4). The $n$-alkanes from the fuel showed an abundance maximum at $\mathrm{C}_{15}$, whereas those from the exhaust showed a maximum at $\mathrm{C}_{20}$, suggesting a preferential loss during combustion and sampling. ${ }^{13} \mathrm{C}$ values of diesel $n$-alkanes range from $-29.1 \%$ o to $-26.5 \%$ (Table 2, Figure 5). Pristane and phytane show lighter values averaging at $-29.8 \%$ and $-31.0 \%$, respectively.

\section{DIESEL FUEL}

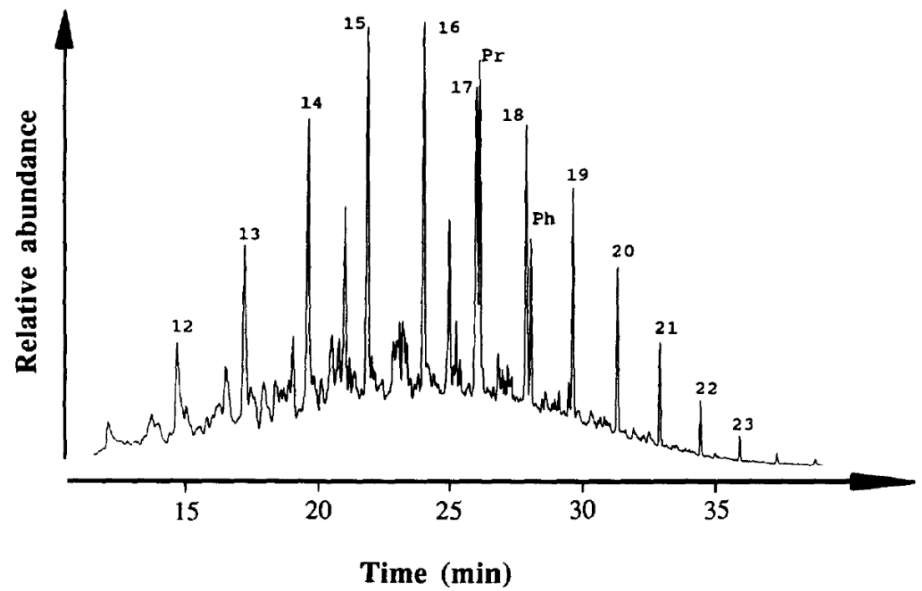

Figure 3. Gas chromatogram of alkanes extracted from the diesel fuel. Pr : pristane, Ph : phytane. 
DIESEL EXHAUST

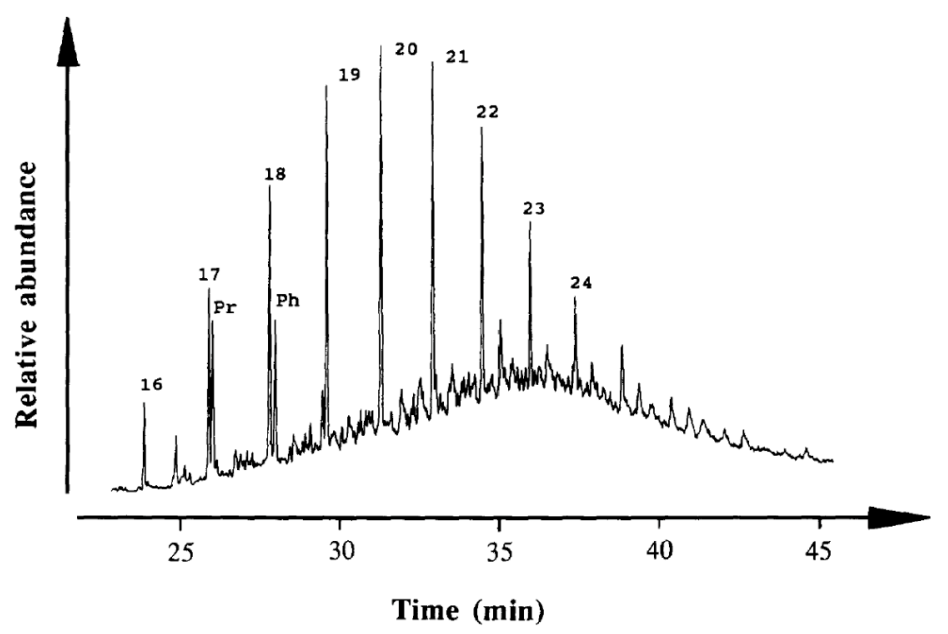

Figure 4. Gas chromatogram of alkanes extracted from the diesel exhaust. $\mathrm{Pr}$ : pristane, $\mathrm{Ph}$ : phytane.

Table 2. Carbon isotopic composition (\%o) of alkanes isolated from diesel fuel and automobile exhaust.

\begin{tabular}{ccc}
\hline Alkane & Fuel & Exhaust \\
\hline $\mathrm{C}_{12}$ & -28.3 & n.d. \\
$\mathrm{C}_{13}$ & -27.9 & n.d. \\
$\mathrm{C}_{14}$ & -27.0 & n.d. \\
$\mathrm{C}_{15}$ & -26.9 & n.d. \\
$\mathrm{C}_{16}$ & -27.2 & -27.4 \\
$\mathrm{C}_{17}$ & -26.5 & -28.0 \\
$\mathrm{C}_{18}$ & -27.0 & -29.1 \\
$\mathrm{C}_{19}$ & -28.3 & -26.8 \\
$\mathrm{C}_{20}$ & -28.5 & -27.4 \\
$\mathrm{C}_{21}$ & -28.9 & -27.6 \\
$\mathrm{C}_{22}$ & -27.7 & -28.0 \\
$\mathrm{C}_{23}$ & -27.6 & -27.5 \\
$\mathrm{C}_{24}$ & n.d. & -27.2 \\
Pristane & -29.6 & -30.1 \\
Phytane & -30.7 & -31.3 \\
\hline
\end{tabular}

Short-chain soil $n$-alkanes and $n$-alkanes from diesel products show close distributions and ${ }^{13} \mathrm{C}$ values. These findings suggest that fuel products, like those emitted by vehicles, are a likely source of soil $n$-alkanes through aeolian transport then deposition onto the soil surface. Removal of pollutants and particulate matter from the atmosphere by adsorption on waxy surfaces of plants (SMITH, 1977, SIMONICH and HITES, 1994) could also play a major role because cropping practices induce a high flux of plant debris into the soil. Crop fields could therefore act as a major sink of pollutants carried by aerosols. 


\section{Diesel fuel and exhaust}

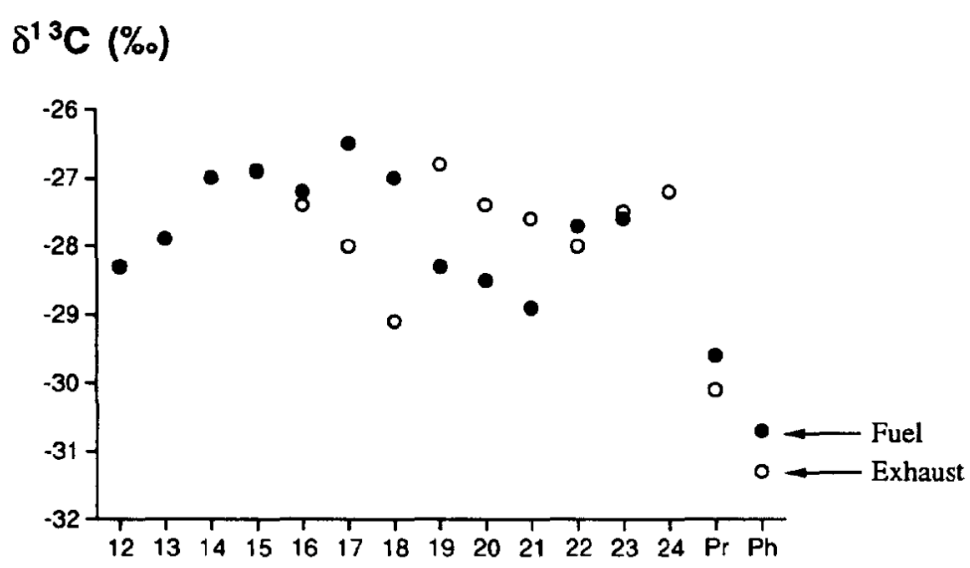

Alkane

Figure 5. Carbon isotopic data for alkanes extracted from diesel fuel and exhaust. $\mathrm{Pr}:$ pristane, $\mathrm{Ph}$ : phytane.

\section{Origin of Soil $\mathbf{C}_{\mathbf{1 6}}-\mathbf{C}_{\mathbf{1 8}} \boldsymbol{n}$-Alkanes}

Several external sources can be considered. First, $\mathrm{C}_{16}-\mathrm{C}_{18} n$-alkanes may be derived from the pre-existing sedimentary rock. However, they should have been biodegraded, or water-washed rapidly after the soil formation, especially after the beginning of tillage where water-washing and biodegradation are strongly enhanced by cropping practices. This view is strengthened by consideration of $n$-alkane absolute concentrations (Table 3). Indeed, at La Minière, absolute concentrations of $\mathrm{C}_{16}, \mathrm{C}_{17}$ and $\mathrm{C}_{18} n$-alkanes average at 33, 27 and $49 \mathrm{ng}$ per $\mathrm{g}$ of soil, respectively, and do not show any systematic decrease nor increase with increasing time of cultivation. They must therefore represent a rather regular input in order to sustain their absolute concentrations in soils. Noteworthy, the absolute concentrations of $\mathrm{C}_{16}-\mathrm{C}_{18}$ soil $n$-alkanes (27-49 ng/g) is in the same concentration level as $\mathrm{C}_{25}-\mathrm{C}_{33} n$-alkanes $(25-232 \mathrm{ng} / \mathrm{g}$ ). This suggests that, given their higher degradability, the amount of $\mathrm{C}_{16}-\mathrm{C}_{18}$ soil $n$-alkanes introduced into the soil over a fixed time period should be even higher than the amount of $\mathrm{C}_{25}-\mathrm{C}_{33}$ soil $n$ alkanes derived from maize waxes. 
Table 3. Absolute concentration of soil $n$-alkanes

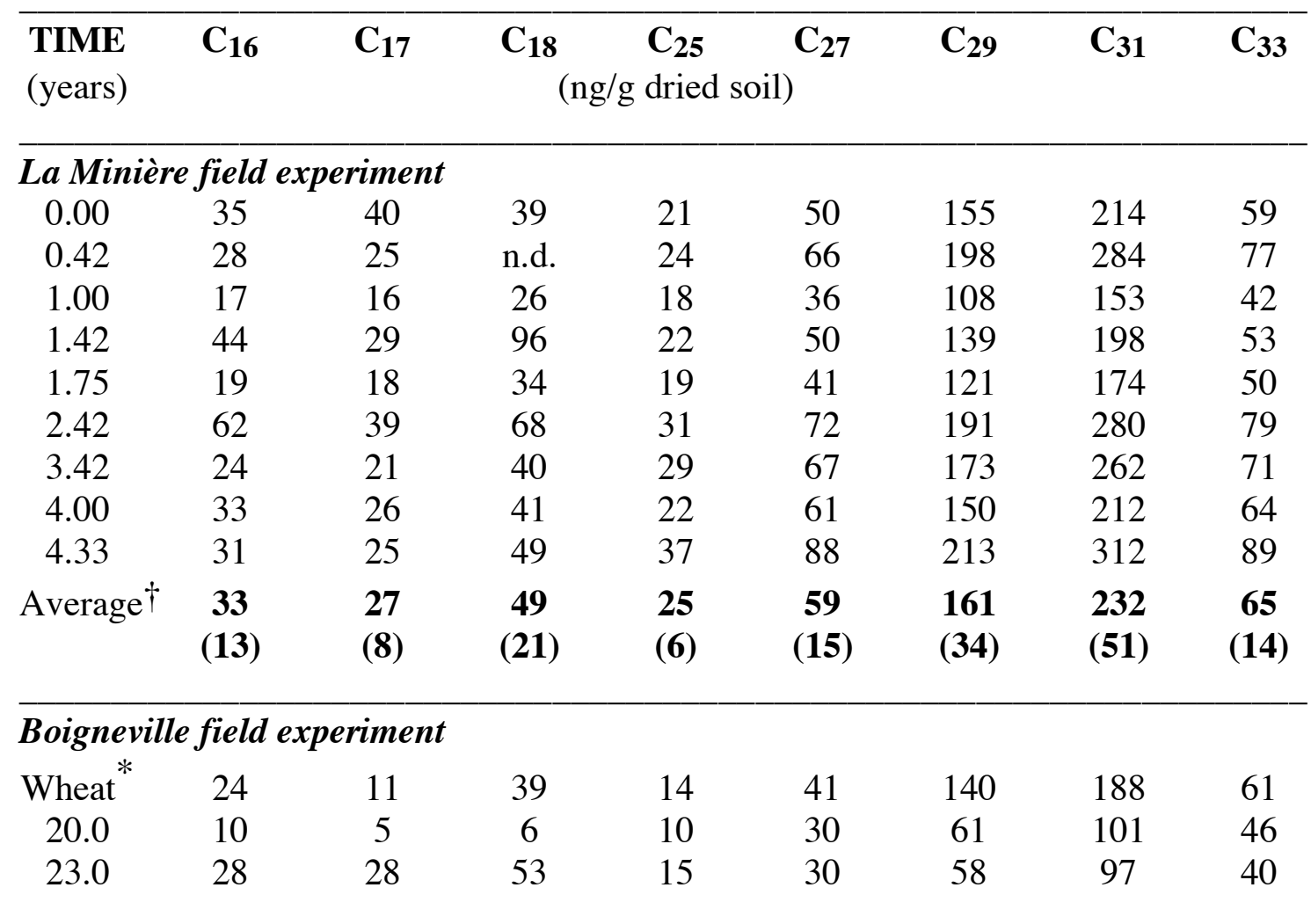

Note: ${ }^{*}$ Soil cultivated 23 years with wheat. n. d. = not determined. ${ }^{\dagger}$ Calculated mean deviation in parenthesis.

Secondly, $\mathrm{C}_{16}-\mathrm{C}_{18}$ soil $n$-alkanes could be derived from algae growing at the soil surface, because atmospheric $\mathrm{CO}_{2}$ represents a carbon source of relatively constant isotopic composition. There are indeed several reports of $\mathrm{C}_{15}-\mathrm{C}_{23} n$-alkanes and $n$-alkenes in microalgae (GELPI et al., 1968, 1970, WEETE, 1976). However, those algal substances show a strong predominance of odd-carbon number homologues, e.g. at $\mathrm{C}_{17}$, which should be retained, at least partly, when algal constituents are transfered to soil organic matter. Such a predominance is not apparent in the $\mathrm{C}_{16}-\mathrm{C}_{18} n$-alkanes distributions (Figure 2, Table 3). Moreover, soil algae fix both atmospheric $\mathrm{CO}_{2}$ and $\mathrm{CO}_{2}$ produced by the degradation of soil organic matter. This soil $\mathrm{CO}_{2}$ must show a significant isotopic increase with increasing time of cultivation due to the input of maize matter. Therefore algal constituents should also show an isotopic shift toward heavier values with increasing time of maize cultivation. A contribution of $\mathrm{C}_{16}-\mathrm{C}_{18}$ soil $n$-alkanes can thus be reasonably excluded here.

The most probable origin of $\mathrm{C}_{16}-\mathrm{C}_{18}$ soil $n$-alkanes is an input from fossil fuels, either by aeolian input, by cropping practices, e.g. fumes from exhausts, or by continuous hydrocarbon seepage from the subsurface. Indeed, their weak even carbon number predominance is usually encountered in petroleums and sediments of medium to high maturity, whereas soil $n$-alkanes in the $\mathrm{C}_{25}-\mathrm{C}_{35}$ range show a strong predominance of odd carbon number homologues, indicative of an immature contribution (Figure 2, TISSOT and WELTE, 1984). Moreover, the isotopic values of $\mathrm{C}_{16}-\mathrm{C}_{18}$ soil $n$-alkanes range from -28.1 to -31.6 (Table 1 ), which is in good agreement, 
with only few exceptions, with isotopic ranges reported in various mature sedimentary rocks and petroleums (CLAYTON and BJORØY, 1994, WILHEMS et al., 1994, BJORØY et al., 1994, LICHTFOUSE et al., 1994b), and in diesel fuel products (this study). On the other hand, the two crop fields studied are both lying in the Paris basin, which is well known for the occurrence of mature Liassic organic matter and petroleums in deep formations (TISSOT et al., 1971, LICHTFOUSE et al., 1994b). Continuous hydrocarbon seepage from the subsurface may thus alternatively account for the persistence of shortchain alkanes in soils at low but detectable levels.

\section{CONCLUSION}

Molecular, ${ }^{13} \mathrm{C}$ and ${ }^{14} \mathrm{C}$ information has been used to decipher the origin of nonpoint source pollutants occurring in soil. These findings show that short-chain $n$-alkanes from crop soils represent a regular input of fossil fuel hydrocarbons either from aerosols, e.g. vehicle exhausts, or from deep sedimentary rocks. Furtehrmore, the absence of isotopic variation during long term labelling experiments can be used to assess the indigenous origin of individual organic substances. This principle may apply to any media that has recorded a well-marked isotopic change : sediments, soils, tree rings, peat, ice, shells, etc.

\section{Acknowledgements}

We thank Dr Timothy Eglinton from Woods Hole Oceanographic Institution for ${ }^{14} \mathrm{C}$ measurements. Dr Michael Engel is greatly acknowleged for his helpful comments in reviewing the manuscript. We are indebted to the Institut National de la Recherche Agronomique, Secteur Environnement Physique et Agronomie, Département de Science du Sol, for financial support.

\section{REFERENCES}

Amblès A., PARlanti É., JAMBu P., MAYOUngou P. and JACQUeSY J. C. (1994) $n$-Alkane oxidation in soil. Formation of internal monoalkenes. Geoderma 64, 111124.

BALABANNE M. and BALESDENT J. (1992) Input of fertilizer-derived labelled N to soil organic matter during a growing season of maize in the field. Soil Biol. Biochem. 24, 89-96.

BALESDEnT J., Mariotti A. and Boisgontier D. (1990) Effect of tillage on soil organic carbon mineralization estimated from ${ }^{13} \mathrm{C}$ abundance in maize fields. J. Soil Sci. 41, 587-596.

BALESDENT J., MARIOTTI A. and GuILlet B. (1987) Natural ${ }^{13} \mathrm{C}$ abundance as a tracer for studies of soil organic matter dynamics. Soil Biol. Biochem. 19, 25-30.

BJORØY M., HALL P. B. and MOE R. P. (1994) Variation in the isotopic composition of single components in the $\mathrm{C}_{4}-\mathrm{C}_{20}$ fraction of oils and condensates. Org. Geochem. 21, 761-776.

BOSSERT I. and BARTHA R. (1984) The fate of petroleum in soil ecosystems. In Petroleum Microbiology (ed. R. M. ATLAS), Chap. 10, pp. 435-473. Macmillan.

ClAYTON C. J. and BJORøY M. (1994) Effect of maturity on ${ }^{13} \mathrm{C} /{ }^{12} \mathrm{C}$ ratios of individual compounds in North Sea oils. Org. Geochem. 21, 737-750.

Collister J. W., LichtFouse É., Hieshima G. and HAYes J. M. (1994) Partial resolution of sources of $n$-alkanes in the saline portion of the Parachute Creek Member, Green River Formation (Piceance Creek Basin, Colorado). Org. Geochem. 21, 645-659. 
Dinel H., Schnitzer M. and Mehuys G. R. (1990) Soil lipids: origin, nature, content, decomposition, and effect on soil physical properties. In Soil Biochemistry (eds. J. M. Bollag and G. STOTZKY), Chap. 8, pp. 397-429. Marcel Dekker.

DURAND B., EsPitAlí́ J. and OUdIN J. L. (1970) Analyse géochimique de la matière organique extraite des roches sédimentaires. III. Accroissement de la rapidité du protocole opératoire par l'amélioration de l'appareillage. Rev. Inst. Fr. Pétr. 25, 1268-1279.

Eglinton T. I., Aluwihare L. I., BAuer J. E., DrufFel E. R. M. and MCNichol A. P. (1996) Gas chromatographic isolation of individual compounds from complex matrices for radiocarbon dating. Anal. Chem. 68, 904-912.

FreEMAN K. H., WAKehAM S. G. and HAYES J. M. (1994) Predictive isotopic biogeochemistry: hydrocarbons from anoxic marine basins. Org. Geochem. 21, 629644.

GelPi E., ORó J., Schneider H. J. and BennetT E. O. (1968) Olefins of high molecular weight in two microscopic algae. Science 161, 700-702.

GELPI E., SCHNEIDER H., MANN J. and ORÓ J. (1970) Hydrocarbons of geochemical significance in microscopic algae. Phytochem. 9, 603-612.

GRIMALT J. and AlBAigÉs J. (1987) Sources and occurrence of $\mathrm{C}_{12}-\mathrm{C}_{22} n$-alkanes distributions with even carbon-number preference in sedimentary environments. Geochim. Cosmochim. Acta 51, 1379-1384.

KISSIN Y. V. (1987) Catagenesis and composition of petroleum: origin of $n$-alkanes and isoalkanes in petroleum crudes. Geochim. Cosmochim. Acta 51, 2445-2457.

LEEUW J. de and LARGEAU C. (1993) A review of macromolecular organic compounds that comprise living organisms and their role in kerogen, coal, and petroleum formation. In Organic Geochemistry, Principles and Applications (eds. M. H. ENGEL and S. A. MACKO), Chap. 2, pp. 23-72. Plenum Press.

LiCHTFOUSE É. (1995) ${ }^{13} \mathrm{C}$ Labelling of soil $n$-hentriacontane $\left(\mathrm{C}_{31}\right)$ by maize cultivation. Tetrahedron Lett. 36, 529-530.

LICHTFOUSE É. (1996) Heterogeneous turnover of molecular organic substances from crop soils as revealed by ${ }^{13} \mathrm{C}$ labelling at natural abundance with Zea mays. Naturwissenschaft., in press.

LICHTFOUSE É. and BUDZINSKI H. (1995) ${ }^{13} \mathrm{C}$ analysis of molecular organic substances, a novel breakthrough in analytical sciences. Analusis 23, 364-369.

LiCHTFOUSE É. and COLLISTER J. W. (1992) Tracing biogenic links of natural organic substances at the molecular level with stable carbon isotopes: $n$-alkanes and $n$ alkanoic acids from sediments. Tetrahedron Lett. 33, 8093-8094.

LiCHTFOUSE É and EGLINTON T. I. (1995) ${ }^{13} \mathrm{C}$ and ${ }^{14} \mathrm{C}$ evidence of pollution of a soil by fossil fuel and reconstruction of the composition of the pollutant. Org. Geochem. 23, 969-973.

LichtFouse É., Berthier G., Houot S., BARriuso E., Bergheaud V. and VALLAEYS T. (1995) Stable carbon isotope evidence for the microbial origin of $\mathrm{C}_{14^{-}}$ $\mathrm{C}_{18} n$-alkanoic acids in soils. Org. Geochem. 23, 849-852.

Lichtfouse É., Albrecht P., BehAR F. and HAYes J. M. (1994b) A molecular and isotopic study of the organic matter from the Paris basin. Geochim. Cosmochim. Acta 58, 209-221.

Lichtfouse É., Derenne S., Mariotti A. and Largeau C. (1994c) Possible algal origin of long chain odd $n$-alkanes in immature sediments as revealed by distributions and carbon isotope ratios. Org. Geochem. 22, 1023-1027. 
LichtFouse É., Elbisser B., BALESDEnT J., MARIOTTI A. and BARdOUX G. (1994a) Isotope and molecular evidence for direct input of maize leaf waxes into crop soils. Org. Geochem. 22, 349-351.

MCCARTHY R. D. and DUTHIE A. H. (1962) A rapid qunatitative method for the separation of free fatty acids from other lipids. J. Lipid Res. 3, 117-119.

Peters K. E. and Moldowan J. M. (1993) The Biomarker Guide. Prentice Hall.

Sicre M. A., MARTY J. C., Lorre A. and Saliot A. (1990) Airborne and vapor phase hydrocarbons over the Mediterranean Sea. Geophys. Res. Lett. 17, 2161-2164.

SiMONICH S. L. and HITES R. A. (1994) Importance of vegetation in removing polycyclic aromatic hydrocarbons from the atmosphere. Nature 370, 49-51.

SMITH W. H. (1977) Removal of atmospheric particulates by urban vegetation : implications for human and vegetative health. Yale J. Biol. Med. 50, 185-197.

SPOONER N., Rieley G., COllister J., LANDER M., CRANWEll P. A. and MAXWELL J. R. (1994) Stable carbon isotopic correlation of individual biolipids in aquatic organisms and a lake bottom sediment. Org. Geochem. 21, 823-827.

Tegelaar E. W., Matthezing R. M., Jansen J. B. H., Horsfield B. and Leeuw J. de (1989) Possible origin of $n$-alkanes in high-wax crude oils. Nature 342, 529531.

Tissot B., Califet-Debyser Y., Deroo G. and Oudin J. L. (1971) Origin and evolution of hydrocarbons in Early Toarcian Shales, Paris Basin, France. Amer. Assoc. Petrol. Geol. Bull. 55, 2177-2193.

Tissot B. P. and WeLte D. H. (1984) Petroleum Formation and Occurrence. Springer.

Volkman J. K., AleXander R., Kagi R. I., Woodhouse G. W. (1983) Demethylated hopanes in crude oils and their applications in petroleum geochemistry. Geochim. Cosmochim. Acta 47, 785-794.

WEETE J. D. (1976) Algal and fungal waxes. In Chemistry and Biochemistry of Natural Waxes (ed. P. E. KolATTUKUDY), Chap. 9, 349-418.

WilHEMS A., LARTER S. R. and HALL K. (1994) A comparative study of the stable carbon isotopic composition of crude oil alkanes and associated crude oil asphaltene pyrolysate alkanes. Org. Geochem. 21, 751-759. 